Table 2. $p K_{1}$ and acute changes in acid-base status in newborn lambs

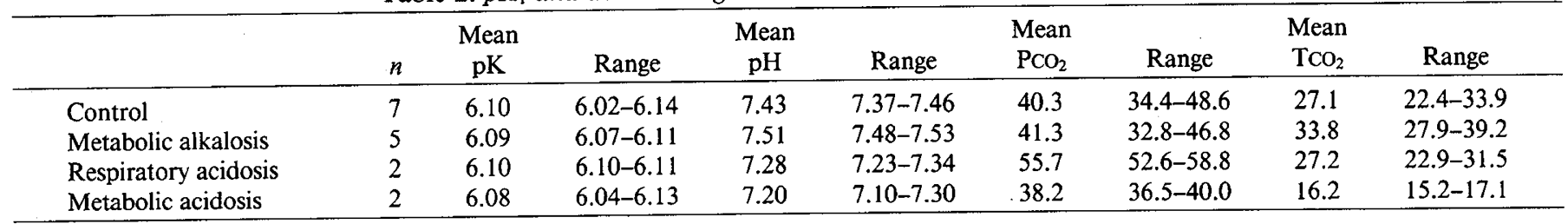

is available. A $19 \%$ error is far less than the $50-170 \%$ errors reported by others $(7,9,10)$. In addition to differences in calibration procedures, a difference in the timing of samples relative to acute disturbances in acid-base status may have been responsible. Nevertheless, our own data in babies, along with those of Austin et al. (1) in critically ill adults, shows that acute illness per se need not lead to alterations in $\mathrm{pK}_{1}$. Our data in lambs suggest that blood samples drawn as soon as $10 \mathrm{~min}$ after a large change in acid-base status may also be assumed to have a $\mathrm{pK}_{1}$ near 6.10 .

\section{REFERENCES}

1. Austin WH, Ferrante V, Anderson C 1968 Evaluation of whole blood $\mathrm{pK}_{1}$ in the acutely ill patient. J Lab Clin Med 72:129

2. Austin WH, Lacombe E, Rand PW, Chatterjee M 1963 Solubility of carbon dioxide in serum from 15 to $38^{\circ} \mathrm{C}$. J Appl Physiol 18:301
3. Gambino SR, Astrup P, Bates RG, Campbell EJM, Chinard FP, Nahas GG, Siggaard-Andersen O, Winters RW 1966 Report of the ad hoc committee on methodology. Ann NY Acad Sci 133:265

4. Hastings AB, Sendroy J Jr, Van Slyke DD 1928 Studies of gas and electrolyte equilibria in blood. XII. The value of $\mathrm{pK}_{1}$ in the Henderson-Hasselbalch equation for blood serum. J Biol Chem 79:183

5. Hood I, Campbell EJM 1982 Is pK 1 OK? N Engl J Med 306:864

6 . Natelson $\mathrm{S} 1951$ Routine use of ultramicro methods in the clinical laboratory. Am J Clin Pathol 21:1153

7. Natelson S, Nobel D 1977 Effect of the variation of $\mathrm{pK}_{1}$ of the HendersonHasselbalch equation on values obtained for total $\mathrm{CO}_{2}$ calculated from $\mathrm{PCO}_{2}$ and $\mathrm{pH}$ values. Clin Chem 23:767

8. Rispens P, Dellebarre CW, Eleveld D, Helder W, Zijlstra WG 1968 The apparent first dissociation constant of carbonic acid in plasma between 16 and $42.5^{\circ}$. Clin Chim Acta 22:627

9. Rosan RC, Enlander D, Ellis J 1983 Unpredicable error in calculated bicarbonate homeostasis during pediatric intensive care: the delusion of fixed $\mathrm{pK}_{1}$. Clin Chem 29:69

10. Trenchard D, Noble M, Guz A 1967 Serum carbonic acid $\mathrm{pK}_{1}$ abnormalities in patients with acid-base disturbances. Clin Sci 32:189

\title{
Semiautomated Enzyme Immunoassay of Thyrotropin as a Mass Screening Test for Neonatal Hypothyroidism
}

\author{
KIYOSHI MIYAI, TSUNEO TSURUHARA, SATOSHI KUSUDA, KAICHIRO ISHIBASHI, \\ MINORU KAWASHIMA, HITOSHI MIZUTA, OSAMU NOSE, HYAKUJI YABUUCHI, AND \\ TOSHIAKI OURA
}

Department of Laboratory Medicine and Central Laboratory for Clinical Investigation [K.M., H.M.], Department of Pediatrics [ON., H.Y.], Osaka University Medical School, Children's Medical Center of Osaka City [T.T., S.K.], Eiken Immunochemical Laboratories [K.I.], Osaka Kessei Laboratories [M.K.], and Association of Environmental Hygiene of Osaka City [T.O.], Osaka Japan

\begin{abstract}
A sensitive, simple, and rapid semiautomated sandwich enzyme immunoassay (EIA) was developed for measuring thyrotropin in dried blood samples on filter paper for use in screening for neonatal hypothyroidism. Good correlation was found between values for thyrotropin determined by this method and those determined by radioimmunoassay (RIA) $(r=0.94)$. In pilot tests on 17,160 newborn infants in the general population, five cases of primary hypothyroidism were detected by both EIA and
\end{abstract}

Received December 30, 1983; accepted June 5, 1984.

Requests for reprints should be addressed to Dr. K. Miyai, Department of Laboratory Medicine, Osaka University Medical School, 1-1-50 Fukushima, Fukushima-ku, Osaka, Japan.

This study was supported in part by Grants from the Ministry of Health and Welfare and Grants-in-Aid for Scientific Research from the Ministry of Education, Science, and Culture of Japan.
RIA. The recall rate was slightly higher in EIA than in RIA. (Pediatr Res 18:1289-1292, 1984)

\section{Abbreviations}

RIA, radioimmunoassay

EIA, enzyme immunoassay

TSH, thyrotropin

IgG, immunoglobulin G

Because irreversible mental retardation in congenital hypothyroidism can be prevented by early treatment, several mass screening methods have been developed for early diagnosis of this 
disease. Among these methods, a sensitive RIA of TSH has been widely used $(1,2,4,7,12,13)$, but this method requires special facilities and the radioisotopes used have short half-lives. The numbers of samples taken in a mass screening program are so large that a nonisotopic method is preferable. In 1976, we developed a competitive EIA of TSH (11) but it was insufficiently sensitive and simple to measure small quantities of TSH in dried blood samples on filter paper used in mass screening. This paper describes a sensitive, simple, and rapid semiautomated sandwich EIA of TSH for this purpose, and compares results of testing newborn babies by both the EIA and RIA methods.

\section{MATERIALS AND METHODS}

The technique used was essentially as described earlier (10) with some modifications.

Rabbit anti-human TSH. Purified human TSH (KABI Diagnostica, Stockholm, Sweden) in doses of 50 to $100 \mu \mathrm{g}$ with complete adjuvant was injected into rabbits several times at 3wk intervals, and blood was withdrawn 1 month after the final injection. The IgG fraction was separated from the antiserum by column chromatography on DEAE-cellulose (anti-TSH-IgG). The anti-TSH-IgG was further purified by affinity chromatography on $\mathrm{CNBr}$-activated Sepharose $4 \mathrm{~B}$ which was coupled with TSH (purified anti-TSH-IgG).

Tube coated with anti-TSH-IgG. Polystyrene tubes were coated with anti-TSH-IgG by the method of Yang and Kennedy (14). To each tube $(13 \times 72 \mathrm{~mm})$ which was soaked in SCAT $20-\mathrm{X}$ and washed with deionized water, $200 \mu \mathrm{l}$ of anti-TSH-IgG solution $(0.3 \mathrm{~g} /$ liter in carbonate buffer consisting of $0.05 \mathrm{M}$ sodium carbonate buffer, $\mathrm{pH}$ 9.0) was added and the tubes were left overnight at $4^{\circ} \mathrm{C}$. Then the solution was removed and the tubes were rinsed with $0.15 \mathrm{M}$ sodium chloride solution and with carbonate buffer. To each tube, $300 \mu \mathrm{l}$ of normal rabbit serum IgG solution $(0.3 \mathrm{~g} / \mathrm{liter}$ in carbonate buffer) was added. The tubes were again allowed to stand overnight at $4^{\circ} \mathrm{C}$, rinsed, and stored at $4^{\circ} \mathrm{C}$.

Anti-TSH-IgG- $\beta$-D-galactosidase complex. The anti-TSH-IgG$\beta$-D-galactosidase complex was prepared by modifications of the method of Ishikawa and Kato (5). The mixture of $1 \mathrm{ml}$ of purified anti-TSH-IgG solution (100 mg/liter) and $100 \mu \mathrm{l}$ of $0.1 \mathrm{M} 2$ mercaptoethylamine hydrochloride was incubated for $90 \mathrm{~min}$ at $37^{\circ} \mathrm{C}$ under nitrogen, and applied to a Sephadex G-25 column $(1 \times 25 \mathrm{~cm})$. The pooled effluent $(8.0$ to $10.3 \mathrm{ml})$ was added dropwise to $2.5 \mathrm{ml}$ of a saturated solution of $N, N^{\prime}-O$-phenylenediamaleimide (Aldrich Chemical Co., Inc., Milwaukee WI) in $0.02 \mathrm{M}$ sodium acetate buffer, $\mathrm{pH} 5.0$, and the mixture was promptly applied to a Sephadex G-25 column $(1 \times 45 \mathrm{~cm})$. Fractions $(5 \mathrm{ml})$ corresponding to the first peak monitored with absorbance at $280 \mathrm{~nm}$ were pooled, and adjusted to pH 6.5 with $0.25 \mathrm{M}$ sodium phosphate buffer, $\mathrm{pH} 7.5$. To the concentrated solution, $0.4 \mu \mathrm{mol}$ of $\beta$-D-galactosidase (EC 3.2.1.23 from Escherichia coli, $5 \mathrm{~g}$ /liter; Boehringer Mannheim, F. R. G.) was added. The mixture was incubated for 20 to $40 \mathrm{~h}$ at $4^{\circ} \mathrm{C}$, and applied to a Sepharose $6 \mathrm{~B}$ column $(1.5 \times 40 \mathrm{~cm})$. The column was equilibrated and eluted with Buffer A consisting of $0.01 \mathrm{M}$ sodium phosphate buffer, containing per liter, $0.1 \mathrm{~mol}$ of $\mathrm{NaCl}$, $1 \mathrm{mmol}$ of $\mathrm{MgCl}_{2}, 1 \mathrm{~g}$ of $\mathrm{NaN}_{3}$, and $1 \mathrm{~g}$ of bovine serum albumin. The pooled fraction with the highest association constant, usually the second peak of antibody activity on RIA, was used. When stored at $4^{\circ} \mathrm{C}$, the complex could be used for at least 6 months.

Standard TSH discs. Heparinized pooled blood from normal subjects with undetectable serum TSH (less than $1.0 \mathrm{mIU} / \mathrm{liter}$ ) separated into plasma and packed cells. Various quantities of standard TSH (Calbiochem-Behring Corp., La Jolla, CA) were dissolved in the plasma and mixed with the packed cells, the mixture being adjusted to the original volume of the blood. When samples of $30 \mu \mathrm{l}$ of the mixture were spotted on the special thick filter paper for use in mass screening (Toyo Kagaku Sangyo Co., Tokyo, Japan), dried spots of about 10-mm diameter were formed.
Procedure of EIA. Reagents were diluted with Buffer A. On the 1st day, two 3-mm dried blood discs (equivalent to about 5.4 $\mu \mathrm{l}$ of blood) and $150 \mu \mathrm{l}$ of normal rabbit serum IgG solution (1 $\mathrm{g} /$ liter) were placed in each anti-TSH-IgG-coated tube, and the mixture was shaken several times and allowed to stand for 40 min. Then $100 \mu \mathrm{l}$ of diluted anti-TSH-IgG- $\beta$-D-galactosidase complex was added and the mixtures were incubated for 20-24 $\mathrm{h}$ at $25^{\circ} \mathrm{C}$ in an incubator. On the 2 nd day, $2 \mathrm{ml}$ of "washing solution" ( $\mathrm{pH} \mathrm{7.6)}$ consisting of $0.01 \mathrm{M}$ phosphate buffer containing, per liter, $0.15 \mathrm{~mol}$ of $\mathrm{NaCl}$ and $1 \mathrm{~g}$ of Tween 20 (Nakarai Chemical Co., Kyoto, Japan) was poured into each tube. The contents of the tube were discarded by inverting the racks with vigorous shaking after covering with a net to prevent the tubes from falling out. This washing step was repeated three times.

The enzyme activity in the tubes was then measured in an analyzer specifically manufactured for this purpose (Shimazu Co., Kyoto, Japan). When the tubes were set in a turntable in an incubator, the following procedures were automatically carried out. The substrate $(250 \mu \mathrm{l}$ of 4-methylumbelliferyl- $\beta$-D-galactopyranoside solution) was dispensed into each tube, and after incubation for $40 \mathrm{~min}$ at $37^{\circ} \mathrm{C}, 2.5 \mathrm{ml}$ of $0.1^{\circ} \mathrm{M}$ glycine buffer ( $\mathrm{pH} 10.3$ ) was added to stop the enzyme reaction. Then the solution was sucked out and the fluorescence was measured in a flow fluorescence spectrometer at $450 \mathrm{~nm}$ with excitation at 370 $\mathrm{nm}$. The data were linked to a computer and the calibration curve, measured values, and distribution of the values were automatically computed.

Procedure of RIA. TSH in two 3-mm dried blood discs was determined by the two-step double antibody method of RIA using an Eiken Cretin-kit (Eiken Immunochemical Laboratories, Tokyo, Japan).

Subjects. Dried blood samples were obtained from 17,160 newborn babies in the general population and from 12 cases of congenital primary hypothyroidism with various TSH concentrations, and from 10 normal babies.

\section{RESULTS}

Fundamental studies. Figure 1 shows a typical standard curve. TSH in blood could be measured at concentrations of 10 to 160 $\mathrm{mIU} /$ liter. There was no cross-reactivity with luteinizing hormone, follicle-stimulating hormone, adrenocorticotropic hormone, prolactin, or human chorionic gonadotropin. The coefficients of variation were 10.6 to $13.0 \%$ (within assay) and 11.6 to $18.3 \%$ (between assays).

TSH concentrations in dried blood samples were determined by RIA $(x)$ and EIA $(y)$. As shown in Figure 2, a good correlation was observed between the values determined by the two methods $(y=1.1 x-6.3 ; n=22, r=0.94, \dot{p}<0.001)$.

Results of screening. Newborn babies in the general population were screened by both EIA and RIA. When the TSH values of the babies were above the cut-off point in the first determination, the TSH concentrations in the remaining samples from these babies were measured concomitantly with other babies in the second detemination, and when the values were again above the cut-off point the babies were recalled for examination. The cutoff point was set at the second percentile (babies with TSH level above the second percentile of distribution of TSH values in the first and second determinations were selected). Of 17,160 babies tested in the general population, 83 cases (1 of 206) were selected for recall by EIA and 52 cases ( 1 of 330) by RIA (Table 1). Among these five patients with hypothyroidism (1 of 3432) were detected by both EIA and RIA. One case of transient hyperthyrotropinemia $(8,9)$ was detected by EIA but not by RIA while one case of severe anemia with normal thyroid function was detected by RIA but not by EIA (third percentile).

\section{DISCUSSION}

The proposed semiautomated EIA of TSH should be very useful for screening for neonatal hypothyroidism as it has the 


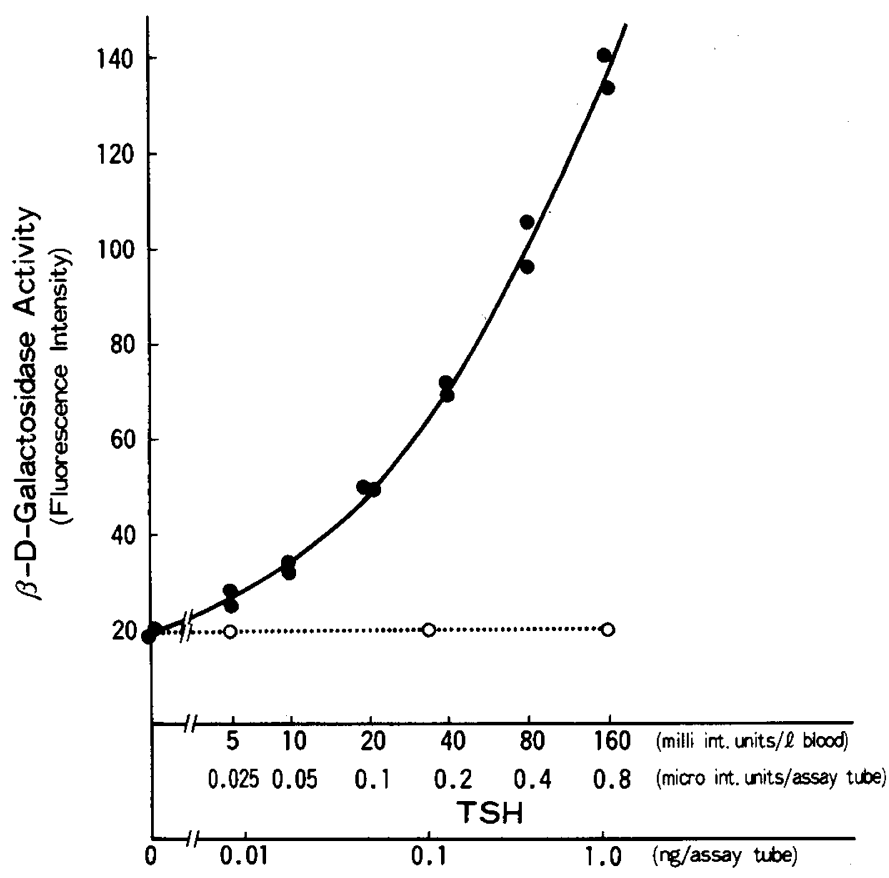

LH. FSH, ACTH, PRL, hCG

Fig. 1. A typical standard curve for EIA of TSH (-). Luteinizing hormone, follicle-stimulating hormone, adrenocorticotropic hormone, prolactin, and human chorionic gonadotropin ( $L H, F S H, A C T H$, $P R L$, and $h C G)(O \ldots O)$ show no cross-reactivity in this assay. One unit of fluorescence intensity corresponds to the intensity of $5 \times 10^{-9} \mathrm{~mol}$ of 4-methylumbelliferone/liter.

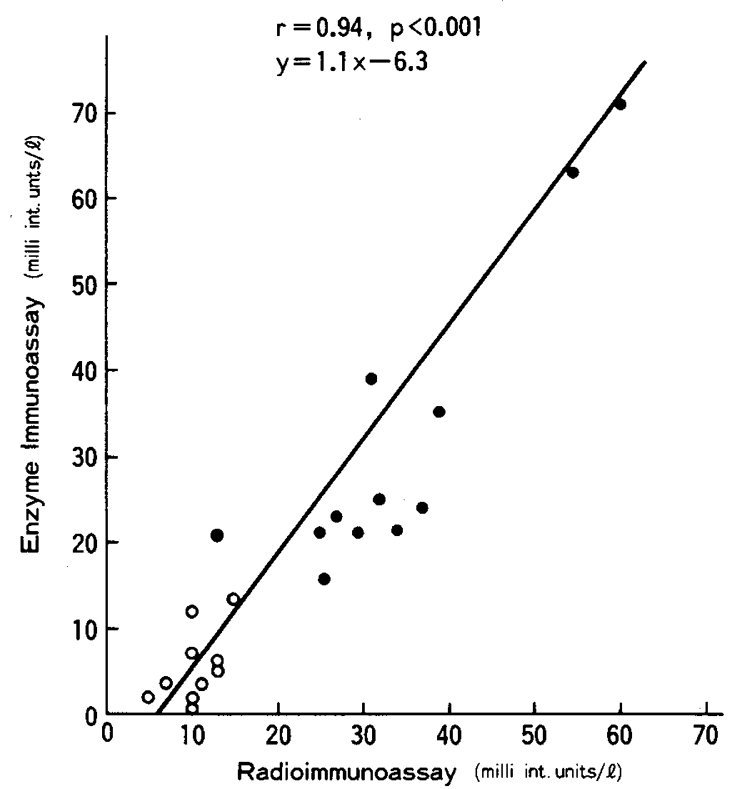

Fig. 2. Correlation between TSH concentrations measured by RIA $(x)$ and EIA $(y)$ in dried blood samples obtained from normal babies $(O)$ and patients with congenital hypothyroidism (-). TSH concentrations are expressed as IU/liter of blood.

Table 1. Summary of results on screening for neonatal hypothyroidism by EIA of TSH

Total infants screened

Recalled for examination

Abnormal cases with elevated TSH

Primary hypothyroidism

Transient infantile hyperthyrotro-

pinemia following advantages. First, all procedures can be done in a routine laboratory. It is sensitive and reproducible. As little as $10 \mathrm{mIU}$ of TSH/liter of blood can be detected in two 3-mm blood discs and the sensitivity is comparable with that of RIA and another sensitive double antibody $\operatorname{EIA}(3,6)$. The withinand between-assay coefficients of variation are acceptable for screening. Since only one tube per sample is used for the whole procedure, there is no need to transfer the reagents. A large number of tubes can be washed at one time and there is no need for centrifugation. Measurement of enzyme activity and processing of data can be done automatically. The procedure can be completed in 2 days. TSH is limited in availability but, in this method, a large amount of easily prepared antiserum is used for coupling with enzyme, and the enzyme-anti-TSH complex is stable for at least 6 months. The cost of reagents for EIA is almost the same as for RIA in Japan. The method is reliable as shown by the good correlation between TSH values determined by EIA and RIA.

The between-assay variation cannot be avoided when dried blood specimens on filter paper are used. Therefore the cutoff point was not fixed at an absolute value, but instead the percentile method was used. In general, it is preferble to decrease both false negative and false positive results. If the cut-off point is lowered, false negative results are decreased but the number of false positive results increases. The reverse is true on raising the cutoff point. The recall rate ( 1 in 206 in EIA versus 1 in 330 in RIA) and "noise" (subjects recalled/abnormal cases: 13.8 versus 10.4) were greater in EIA than RIA. One case with normal serum TSH and severe anemia which may cause increasing TSH concentration in dried blood samples was detected by RIA but not by EIA. These findings indicate that the RIA seems to be better than the EIA method. However, the fact that a case of transient hyperthyrotropinemia with slightly elevated TSH was detected by EIA but not by RIA indicates that EIA seems to be more sensitive. The reason for some discrepancies between results by EIA and RIA, particularly the negative bias in correlation between EIA and RIA (Fig. 2) and high TSH values by EIA but low value by RIA and vice versa in mass screening is unknown. False positive results may be obtained by EIA when the enzymeanti-TSH complex is bound to anti-TSH coating the tube through some unknown factors, such as anti-rabbit $\gamma$-globulin antibody, and/or the enzyme-anti-TSH complex or nonspecific fluorescent substances remain in the washed tube. Further studies are required on this problem.

Acknowledgments. We thank Dr. N. Amino and our colleagues within the divisions for their technical and secretarial assistance.

\section{REFERENCES}

1. Delange F, Beckers C, Höfer R, König MP, Monaco F, Varrone S 1979 Neonatal screening for congenital hypothyroidism in Europe. Report of the Newborn Committee of the European Thyroid Association. Acta Endocrinol Suppl 90:1

2. Fisher DA, Dussault JH, Foley TP Jr, Klein AH, LaFranchi S, Larsen PR, Mitchell ML, Murphey WH, Walfish PG 1979 Screening for congenital hypothyroidism: results of screening one million North American infants. $J$ Pediatr 94:700

3. Imagawa $M$, Ishikawa $E$, Yoshitake $S$, Tanaka $K$, Kan $H$, Inada $M$, Imura $H$, Kurosaki H, Tachibana S, Takagi M, Nishiura M, Nakazawa N, Ogawa H, Tsunetoshi Y, Nakajima K 1982 A sensitive and specific sandwich enzyme immunoassay for human thyroid-stimulating hormone. Clin Chim Acta $126: 227$

4. Irie M, Enomoto K, Naruse H 1975 Measurement of thyroid stimulating hormone in dried blood spot. Lancet 2:1233

5. Ishikawa E, Kato K 1978 Ultrasensitive enzyme immunoassay. Scand J Immunol 8 (suppl):43

6. Kato N, Ishii S, Naruse H, Irie M, Arakawa H, Tsuji A 1980 Enzyme immunoassay of thyroid-stimulating hormone using dried blood samples. A simple technique of screening for congenital hypothyroidism. Anal Lett 13:1555

7. Klein AH, Agustin AV, Foley TP Jr 1974 Successful laboratory screening for congenital hypothyroidism. Lancet 2:77

8. Miyai K, Amino N, Nishi K, Fujie T, Nakatani K, Nose $O$, Harada T, Yabuuchi H, Doi K, Yamamoto T, Satake R, Tsuruhara T, Oura T 1979 Transient infantile hyperthyrotropinemia. Report of a case. Arch Dis Child $54: 965$ 
9. Miyai K, Harada T, Nose O, Yabuuchi H, Mizuta H, Nishi K, Fujie T, Nakatani K 1980 Transient infantile hyperthyrotropinemia. In: Stockigt JR, Nagataki S (eds) Thyroid Research VIII. Australian Academy of Science, Canberra, p 33

10. Miyai K, Ishibashi K, Kawashima M 1981 Two-site immunoenzymometric assay for thyrotropin in dried blood samples on filter paper. Clin Chem 27:1421

11. Miyai K, Ishibashi K, Kumahara Y 1976 Enzyme immunoassay of thyrotropin. Clin Chim Acta 67:263
12. Miyai K, Nishi K, Kawashima M, Oura T, Tsuruhara T 1976 An improved assay of thyrotropin in dried blood samples on filter paper as a screening test for neonatal hypothyroidism. Clin Chim Acta 73:241

13. Miyai K, Oura T, Kawashima M, Tsuruhara T, Hase Y, Ichihara K, Amino N, Nishi K, Fujie T, Nankatani K, Azukizawa M, Nose O 1978 A new method of paired thyrotropin assay as a screening test for neonatal hypothyroidism. J Clin Endocrinol Metab 47;1028

14. Yang J, Kennedy MT 1979 Evaluation of enzyme-linked immunosorbent assay for the serodiagnosis of amebiasis. $\mathbf{J}$ Clin Microbiol 10:778

\title{
Apparent Absence of Cystic Fibrosis Sweat Factor on Ion-selective and Transport Properties of the Perfused Human Sweat Duct
}

\author{
JAN BIJMAN AND PAUL M. QUINTON \\ Division of Biomedical Sciences, University of California, Riverside, California 92521-0121 [J.B., P.M.Q.] and \\ Department of Physiology, University of California, Los Angeles, California 90024 [P.M.Q.]
}

\begin{abstract}
Several previous studies have reported that a substance in exocrine products from cystic fibrosis (CF) patients is inhibitory to the transport of $\mathrm{NaCl}$ in several biological preparations. We have recently developed techniques for studying a target CF tissue, the eccrine sweat duct, and determined that salt absorption in the CF sweat duct appears to be decreased due to an impermeability to Cl. To determine whether this property might be induced, we have examined the sweat from patients with $C F$ for potential influences on the ion-reabsorptive and ion-selective properties of sweat ducts from normal subjects. Isolated segments of sweat ducts from healthy volunteers were microperfused in vitro with concentration-adjusted sweat collected after thermal stimulation from CF patients and from normal subjects. The eccrine sweat duct may be best considered as a tight epithelium through which the mucosal uptake of $\mathrm{NaCl}$ proceeds via separate $\mathrm{Na}^{+}$and $\mathrm{Cl}^{-}$pathways. As such, inhibitory actions of CF fluids should be exerted via an inhibition on one, or both, pathways, and should be expected to 1 ) inhibit the electrolyte transport activity and 2) alter the ion-selective properties of normal ductal tissue. We were unable to detect any effect of CF sweat on either property of the normal duct. (Pediatr Res 18:1292-1296, 1984)
\end{abstract}

\section{Abbreviations}

CF, cystic fibrosis

$P D$, potential difference

Received January 2, 1984; accepted June 5, 1984.

Reprint requests may be addressed to Jan Bijman, Division of Biomedical Sciences, University of California, Riverside, CA 92521-0121.

This work was supported by awards from the Getty Oil Co., the Gillette Co., and by National Institutes of Health Grant AM 26547.
The inherited autosomal recessive disease, cystic fibrosis, is a generalized disorder of the exocrine glands. One of the most characteristic features of the disease is abnormally elevated $\mathrm{NaCl}$ in the sweat which is due to decreased electrolyte absorption in the ductal segment of the sweat gland. It has been postulated that the abnormal electrolyte transport in the CF sweat duct is due to a transport-inhibiting substance present in CF sweat (6, 11). It was further suggested that a similar inhibitory substance may be present in other exocrine secretions since saliva from CF patients was reported to inhibit electrolyte reabsorptive processes in other tissues as well $(8,22,24)$.

Many of the types of tissues that apparently exhibit abnormal electrolyte transport in cystic fibrosis also retain several characteristics in common. That is, the sweat duct (13), the salivary duct $(1,4)$, the colon $(24)$, and the respiratory mucosa (7) are all sensitive to the $\mathrm{Na}^{+}$channel blocker, amiloride. All are capable of generating a lumen-negative transepithelial electrical potential. And in addition with the possible exception of respiratory epithelia, most, if not all, of the above tissues are characterized by hypertonic fluid transport, stimulated by aldosterone, and are reported to be inhibited by exocrine secretions from CF patients. To our knowledge, the respiratory mucosa has not been examined for these properties. These observations and characteristics have led to the suggestion that a CF inhibitory substance may act similarly to amiloride $(21,24)$. If the substance is a transport inhibitor, and particularly if it resembles amiloride, we should not only expect inhibition of ion transport, but also alterations in electrophysiological properties of the normal duct as well.

In addition, there are at least two other reasons for re-examining the possibility of a transport inhibitory substance in $\mathrm{CF}$ sweat. First, we have now developed methods for assaying ion transport activity and electrophysiological properties of the isolated sweat duct in vitro making it possible to test the response of a tissue that is known to be markedly affected in the disease. This feature, in addition to the ability to control conditions maximally, should make the preparation an optimal system for bioassay. Secondly, we recently found that the negative potential 